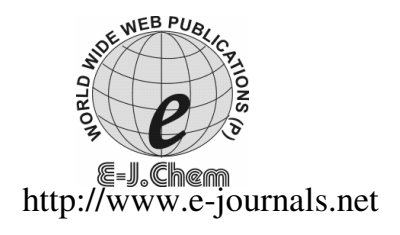

ISSN: 0973-4945; CODEN ECJHAO

E-Journal of Chemistry 2011, 8(1), 405-414

\title{
Synthesis of Some More Fluorine Heterocyclic Nitrogen Systems Derived From Sulfa Drugs as Photochemical Probe Agents for Inhibition of Vitiligo Disease-Part I
}

\author{
REDA M. ABDEL-RAHMAN, \\ MOHAMMAD SALEH I.T. MAKKI and WAFA A.BAWAZIR \\ Department of Chemistry, Faculty of Science \\ King Abdul-Aziz University, P.O. Box 80203, Jeddah 21315, Saudi Arabia \\ wa_baker@hotmail.com \\ Received 11 February 2010; Accepted 7 April 2010

\begin{abstract}
Some more new bioactive fluorine heterocyclic systems containing sulfur and nitrogen as five-membered rings: pyrazoline, imidazole, imidazolopyrimidine, thiazolidinone and 1,2,4-triazole derivatives (3-13) have been synthetically derived from the interaction of sulfa drugs with fluorine aromatic aldehyde and/or hexa fluoroacetic anhydride followed by heterocyclization reactions. Former structures of inhibition of Vitiligo diseases, in compare with Nystatin and Nalidixic acid.
\end{abstract} \\ the targets have been deduced upon the help of elemental and spectral data.. \\ Compounds 7a-f, 10c and $\mathbf{1 3}$ could be used as photochemical probe agents for
}

Keywords: Synthetic, Fluoroheterocyclic, Inhibition of Vitiligo.

\section{Introduction}

In recent years, human pathogenic microorganisms have developed resistance in response to indiscriminate use of commercial antimicrobial drugs commonly employed in the treatment of infectious diseases ${ }^{1}$. On the other hand, fluorine organic and sulfa-compounds exhibited a wide-range of pharmaceutical properties, in addition, a large number of heterocyclic nitrogen systems showed biological activities as anti HIV and anticancer agents ${ }^{2-6}$. Thus, the present work mainly aims synthesis of various fluorinated heterocyclic systems via combination of both fluorine compounds and sulfa drugs in view of their use as photochemical probe agents for inhibition of Vitiligo disease in compare with nystatin and nalydixic acid.

\section{Experimental}

Melting points were determined with an electrochemical Bibby Stuart Scientific melting point SMP (US) apparatus. IR spectra recorded for $\mathrm{KBr}$ disc on a Perkin Lemer Spectrum RXI FT-IR system No. 55529. $\mathrm{H}^{1}$ NMR were determined for solution in deuterated DMSO with a 
Bruker NMR advance DPX400 MH using TMS as an internal standard. ${ }^{13} \mathrm{C}$ spectra were recorded on a VXR-300 $(75 \mathrm{MHz})$ Varian spectrometer operating at room temperature. Mass spectra were measured on GCMS-Q 1000-Ex Spectrometer. Electronic absorption spectra were recorded on Shimadzu UV and Visible 3101 pc spectrophotometer. Microanalysis (Sulfury) were performed by the Micro-analysis center of Cairo university, Egypt.

\section{Methodology}

\section{Preparation of acetyl/benzoyl acetanilide $(\mathbf{1} \boldsymbol{a}, \boldsymbol{b})$}

To preheated ethyl acetoacetate and /or benzoyl ethylacetoacetate $(0.01 \mathrm{~mol})$, sulfanilamide (0.01 mol) was added then warmed at $100-110^{\circ} \mathrm{C}$ for $15-20 \mathrm{~min}$. The solid thus obtained was washed with diethylether and dried to give $\mathbf{1 a}$ and $\mathbf{1 b}$ respectively. $\mathbf{1 b} \mathrm{C}_{15} \mathrm{H}_{14} \mathrm{~N}_{2} \mathrm{SO}_{4}(318$ MW), S\%: 9.30 (Calcd. 10.6), yield 75\%: m.p 229-230 ${ }^{\circ} \mathrm{C}$. IR-DRIFT: $\left(\mathrm{cm}^{-1}\right), 3200,3100$, 3040, 2850, 1675, 1650, 1640, 1440, 1350; $\mathrm{H}^{1} \mathrm{NMR}: \delta$ 4.2(d, 2H), 5.20(s,1H), 6,8-6.5 (m, $5 \mathrm{H}), 7.7-7.5(\mathrm{~m}, 4 \mathrm{H}), 7.9(\mathrm{~s}, 1 \mathrm{H}), \mathbf{1 a}, \mathrm{C}_{10} \mathrm{H}_{12} \mathrm{~N}_{2} \mathrm{SO}_{4}(256 \mathrm{MW})$; yield $70 \%$ : m.p. $177-178{ }^{\circ} \mathrm{C}$; S\%: 11.87(Calcd. 12.5).

\section{Synthesis of 3-arylamino-5-methyl/ phenyl-pyrazoline $(\mathbf{2} \boldsymbol{a}, \boldsymbol{b})$}

Equimolar mixture of compound 1a,b and hydrazine hydrate in THF $(50 \mathrm{~mL})$ was refluxed for $2 \mathrm{~h}$ then cooled. The resulted solid was crystallized from THF to give $\mathbf{2 a}$ and $\mathbf{2 b}$ respectively. 2a: ${ }_{10} \mathrm{H}_{12} \mathrm{~N}_{4} \mathrm{SO}_{2}$ (252 MW), S\%:11.92(Calcd. 12.69); yield 75\%; m.p. 145-155 ${ }^{\circ} \mathrm{C}$; 2b: $\mathrm{C}_{15} \mathrm{H}_{14} \mathrm{~N}_{4} \mathrm{SO}_{2}$ (314 MW), S\%: 9.17(Calcd. 10.1); yield 75\%; m.p. 245-247 ${ }^{\circ} \mathrm{C}$; IRDRIFT: $\left(\mathrm{cm}^{-1}\right) 3200,3129,1624,1591,1429,1140,768 ; \mathrm{H}^{1} \mathrm{NMR}: \delta$ 7.9(s, 1H), 7.0-6.6 $(\mathrm{m}, 9 \mathrm{H}), 7.4(\mathrm{~s}, 1 \mathrm{H}), 5.4(\mathrm{~s}, 1 \mathrm{H}), 3.4(\mathrm{~s}, 1 \mathrm{H}), \mathrm{UV}$ Vis $(\mathrm{EtOH}): \lambda_{\max } 276 \mathrm{~nm}$.

Synthesis of 1-trifluoroacetyl-3-( sulfonamoyl phenyl-4-yl-trifluoro acetyl amino)5-phenyl pyrazoline (3)

To a mixture of compound $\mathbf{2 b}(0.01 \mathrm{~mol})$ in THF $(20 \mathrm{~mL})$ and hexafluoro acetic anhydride $(0.02 \mathrm{~mol})$ was added and refluxed for $2 \mathrm{~h}$, cooled. The obtained solid was crystallized from THF to give 3. $\mathrm{C}_{19} \mathrm{H}_{12} \mathrm{~N}_{4} \mathrm{~F}_{6} \mathrm{SO}_{4}$ (506 MW), S\%: 6.0 (Calcd. 6.32); yield 80\%, m.p. 136-137 ${ }^{\circ} \mathrm{C}$; IR-DRIFT: $\left(\mathrm{cm}^{-1}\right)$ 3020, 1760, 1683, 1503,1350, 850, 663; EI-MS: $\mathrm{m} / \mathrm{z}$ (Int. \%) 506 (3), 353(18), 255(19), 194(8), 185(10), 159(100), 143(18); UV Vis (EtOH): $\lambda_{\max } 288 \mathrm{~nm}$.

\section{Preparation of oxazole-5-one derivative 4}

A mixture of $p$-fluorobenzaldehyde $(0.01 \mathrm{~mol})$, hippuric acid $(0.01 \mathrm{~mol})$ in acetic anhydride $(50 \mathrm{~mL})$, anhydrous sodium acetate $(10 \mathrm{~g})$ was refluxed for $4 \mathrm{~h}$, cooled then poured onto ice. The produced solid was washed with cold water and crystallized from glacial acetic acid to give 4. $\mathrm{C}_{16} \mathrm{H}_{10} \mathrm{NF}_{6} \mathrm{O}_{2}(267, \mathrm{MW})$, yield $60 \%$; m.p. 185-187 ${ }^{\circ} \mathrm{C}$; IR-DRIFT: $\left(\mathrm{cm}^{-1}\right) 3050$, 2920, 1680, 1620, 1050,920,870, 650 .

\section{Synthesis of 1-(sulfonamoylphenyl)-4-(4`-fluorobenzylidene)imidazol-5-one (5)}

Equimolar amounts of compound $\mathbf{4}$ and sulfapyridine in dry pyridine $(100 \mathrm{~mL})$ was heated under reflux for $12 \mathrm{~h}$, cooled then poured onto ice- $\mathrm{HCl}$. The solid that obtained was filtered off and washed with cold water and crystallized from dry pyridine to give $5 . \mathrm{C}_{27} \mathrm{H}_{19} \mathrm{~N}_{4} \mathrm{FSO}_{3}$ (498 MW), S\%: 5.97(Calcd. 6.42); yield 75\%; m.p.169-170 ${ }^{\circ} \mathrm{C}$; IR-DRIFT: $\left(\mathrm{cm}^{-1}\right) 3240$, 3059, 1790, 1596, 1390,1159, 1323, 870, 693; EI-MS: m/z (Int. \%) 498(1), 341(5), 275(3), 266(18), 184(94), 107(8), 106(9), 104(100), 103(8); UV Vis (EtOH): $\lambda_{\max } 385,365,348,268 \mathrm{~nm}$.

\section{Synthesis of imidazolopyrimidinone (6)}

A mixture of compound $5(0.01 \mathrm{~mol})$ and thiourea $(0.01 \mathrm{~mol})$ in ethanolic $\mathrm{NaOH}$ $(5 \%, 100 \mathrm{~mL})$ was refluxed for $2 \mathrm{~h}$, cooled then poured onto ice-HCl. The produced solid 
was filtered off and crystallized from EtOH to give 6. $\mathrm{C}_{28} \mathrm{H}_{21} \mathrm{~N}_{6} \mathrm{FSO}_{3}(540 \mathrm{MW}), \mathrm{S} \%: 5.56$ (Calcd. 5.92); yield 75\%; m.p.120 ${ }^{\circ} \mathrm{C}$; IR-DRIFT: $\left(\mathrm{cm}^{-1}\right)$ 3318, 3132, 1733, 1577, 1538,1444, 1374, 1351, 1218, 796, 692; $\mathrm{H}^{1} \mathrm{NMR}$ : $\delta 10(\mathrm{~s}, 1 \mathrm{H}), 9.2(\mathrm{~s}, 1 \mathrm{H}), 8.3-6.8(\mathrm{~m}, 13 \mathrm{H})$, 4.3-4 (m,2H); UV Vis (EtOH): $\lambda_{\max } 305,275 \mathrm{~nm}$.

\section{Preparation of Schiff's base $7(\boldsymbol{a}-\boldsymbol{f})$}

Equimolar mixture of $p$-fluorobenzaldehyde and sulfa drugs; sulfanilamide, sulfabenzamide, sulfaisoxazole, sulfadiazine, sulfamerazine and sulfaguanidine respectively, in glacial acetic acid $(20 \mathrm{~mL})$ was heated under refluxing for $1 \mathrm{~h}$, cooled then poured onto ice. The yielded solid was filtered off and crystallized from acetic acid to give 7a-f, in good yield $70 \%$.

7a: $\mathrm{C}_{13} \mathrm{H}_{11} \mathrm{~N}_{2} \mathrm{FSO}_{2}$ (278 MW), S\%: 10.70 (Calcd. 11.51); m.p.129-130 ${ }^{\circ} \mathrm{C}$.

7b: $\mathrm{C}_{20} \mathrm{H}_{15} \mathrm{~N}_{2} \mathrm{FSO}_{3}$ (382 MW), S\%: 7.95 (Calcd. 8.37); m.p.229-230 ${ }^{\circ} \mathrm{C}$.

7c: $\mathrm{C}_{16} \mathrm{H}_{12} \mathrm{~N}_{3} \mathrm{FSO}_{3}$ (345 MW), S\%: 8.71 (Calcd. 9.27); m.p.211-212 ${ }^{\circ} \mathrm{C}$.

7d: $\mathrm{C}_{17} \mathrm{H}_{13} \mathrm{~N}_{4} \mathrm{FSO}_{2}$ (356 MW), S\%: 8.08 (Calcd. 8.98); m.p.149-150 ${ }^{\circ} \mathrm{C}$.

7e: $\mathrm{C}_{18} \mathrm{H}_{15} \mathrm{~N}_{4} \mathrm{FSO}_{2}$ (370 MW), S\%: 7.94 (Calcd. 8.64); m.p.359-360 ${ }^{\circ} \mathrm{C}$.

7f: $\mathrm{C}_{21} \mathrm{H}_{16} \mathrm{~N}_{4} \mathrm{~F}_{2} \mathrm{SO}_{2}$ (426 MW), S\%: 6.76 (Calcd. 7.51); m.p. $186-187{ }^{\circ} \mathrm{C}$.

7e; IR-DRI-FT: $\left(\mathrm{cm}^{-1}\right) 3375,1622,1612,1582,1442,1402,1315,1230,789,6714$; UV Vis (EtOH): $\lambda_{\max } 375,305,275 \mathrm{~nm}$.

\section{Synthesis of 4-thiazolinones $8(\boldsymbol{a}, \boldsymbol{b})$}

A mixture of 7e and/or $7 \mathbf{f}(0.01 \mathrm{~mol})$ and thioacetic acid $(0.02 \mathrm{~mol})$ in dry dioxan $(50 \mathrm{~mL})$ was refluxed for $12 \mathrm{~h}$, cooled, then poured onto $\mathrm{H}_{2} \mathrm{O}-\mathrm{K}_{2} \mathrm{CO}_{3}$. The obtained solid was crystallized from dry dioxan to give 8a and/or 8b in $60 \%$ yield. 8a: $\mathrm{C}_{20} \mathrm{H}_{17} \mathrm{~N}_{4} \mathrm{FS}_{2} \mathrm{O}_{3}$ (444 MW), S\%: 13.54 (Calcd. 14.41); m.p.151-152 ${ }^{\circ} \mathrm{C}$. EI-MS: $m / z$ (Int. \%) 444(4), 398(18), 370(12), 149(70), 123(82), 110(75), 109(100), 102(18). 8b: $\mathrm{C}_{23} \mathrm{H}_{18} \mathrm{~N}_{4} \mathrm{~F}_{2} \mathrm{~S}_{2} \mathrm{O}_{3}$ (500 MW), S\%: 12.03 (Calcd. 12.80); m.p.156-157 ${ }^{\circ} \mathrm{C}$; IR-DRI-FT: $\left(\mathrm{cm}^{-1}\right)$ 3250, 1682, 1592, 1575, 1549, 1506, 1405, 1155, 792, 644 ; $\mathrm{H}^{1} \mathrm{NMR}$ : $\delta$ 8.2(s, 1H),7.9-7.3, 7.2-6.7 (each m,4H, 4H), 4.3-4.0 (m,2H), 3.2(s,1H) 2.5(m, 2H); UV Vis (EtOH): $\lambda_{\max } 400,328,277 \mathrm{~nm}$.

Synthesis of 5-trifluoroacetyl-2H-5H-2,3-diarylthiazolidin-4-one (9)

A mixture of compound $\mathbf{8 b}(0.01 \mathrm{~mol})$ and hexafluoroacetic anhydride $(1 \mathrm{~mol})$ in THF $(20 \mathrm{~mL})$ was refluxed for $2 \mathrm{~h}$, cooled then poured onto ice. The produced solid was crystallized from THF to give 9 in good yield $80 \% . \mathrm{C}_{25} \mathrm{H}_{17} \mathrm{~N}_{4} \mathrm{~F}_{5} \mathrm{~S}_{2} \mathrm{O}_{4}(596 \mathrm{MW}), \mathrm{S} \%$ : 10.09 (Calcd. 10.73); m.p.130-132 ${ }^{\circ}$ C; IR-DRI-FT: $\left(\mathrm{cm}^{-1}\right)$ 3500, 3200, 3150, 3020, 2980, 1690, 1667, 1580, 1330, 820,664; UV Vis (EtOH): $\lambda_{\max } 390,279 \mathrm{~nm}$.

\section{Preparation of 1,2-diiminoaryl-3,4-dihydroxybutene (10a-c)}

Equimolar amounts of squaric acid $(0.01 \mathrm{~mol})$ and the selective sulfa drugs as: sulfanilamide, sulfabenzamide and or sulfamerazine $(0.01 \mathrm{~mol})$ in DMF $(20 \mathrm{~mL})$ was refluxed for $1 \mathrm{~h}$, cooled then poured onto ice and extracted with diethyl ether. The solid thus obtained was crystallized to give 10a-c in good yield $80 \%$.

10a: $\mathrm{C}_{16} \mathrm{H}_{14} \mathrm{~N}_{4} \mathrm{~S}_{2} \mathrm{O}_{6}\left(422 \mathrm{MW}\right.$ ), $\mathrm{S} \%: 14.09$ (Calcd. 15.16); m.p. $>360{ }^{\circ} \mathrm{C}$.

10b: $\mathrm{C}_{30} \mathrm{H}_{22} \mathrm{~N}_{4} \mathrm{~S}_{2} \mathrm{O}_{8}$ (630 MW), S\%: 9.54 (Calcd. 10.15); m.p. $>360{ }^{\circ} \mathrm{C}$.

10c: $\mathrm{C}_{26} \mathrm{H}_{22} \mathrm{~N}_{8} \mathrm{~S}_{2} \mathrm{O}_{6}$ (606 MW), S\%: 10.03 (Calcd. 10.56); m.p. $>360{ }^{\circ} \mathrm{C}$.

Synthesis of 1,2-diiminoaryl-3,4-di(trifluoroacetoxy)-cyclo butene (11)

A mixture of compound 10b $(0.01 \mathrm{~mol})$ and hexafluoroacetic anhydride $(1 \mathrm{~mL})$ in THF $(20 \mathrm{~mL})$ was warmed and refluxed for $1 \mathrm{~h}$ then cooled. The obtained solid was crystallized from THF to give 11, in $75 \%$ yield. $\mathrm{C}_{34} \mathrm{H}_{20} \mathrm{~N}_{4} \mathrm{~F}_{6} \mathrm{~S}_{2} \mathrm{O}_{10}$ (822 MW), S\%: 7.31 (Calcd. 7.78); 
m.p. $>360{ }^{\circ}$ C; EI-MS: $m / z$ (Int. \%) 822 (8), 260(24), 239(28), 210(2), 194(34), 184(32), 156(28), 111(86), 109(100), 105(65); IR-DRI-FT: $\left(\mathrm{cm}^{-1}\right) 3365,1738,1687,1625$, 1591,1537, 1305, 1091, 754, 681; $\mathrm{H}^{1} \mathrm{NMR}: \delta$ 8.0-7.9(s,1H,1H), 7.8-7.6(m,18H), 4.3,4.1 (s,1H,1H); UV Vis (EtOH): $\lambda_{\max } 410,350,277 \mathrm{~nm}$.

\section{Preparation of $\mathrm{N}$-di(trifluoroactyl)sulfanilamide (12)}

A mixture of sulfanilamide $(0.01 \mathrm{~mol})$ in THF $(50 \mathrm{~mL})$ and hexafluoroacetic anhydride $(2 \mathrm{~mL})$ was added drop wise then refluxed for $2 \mathrm{~h}$, cooled. The obtained solid was crystallized from THF to give 12, in good yield 70\%; $\mathrm{C}_{10} \mathrm{H}_{6} \mathrm{~N}_{2} \mathrm{~F}_{6} \mathrm{SO}_{4}(364 \mathrm{MW}), \mathrm{S} \%$ : 8.17(Calcd. 8.79); m.p. 212-213 ${ }^{\circ}$ C; IR-DRI-FT: $\left(\mathrm{cm}^{-1}\right) 3366,1706,1597,1330,1285,1245$, 769, 683; UV Vis (EtOH): $\lambda_{\max } 350,275 \mathrm{~nm}$.

\section{Synthesis of 3,5-di(trifluoromethyl)-4-(4`-sulfonamoylphenyl)-1,2,4-triazole (13)}

To compound $12(0.01 \mathrm{~mol})$ in THF $(20 \mathrm{~mL})$, hydrazine hydrate $(0.01 \mathrm{~mol})$ was added drop wise then refluxed for $2 \mathrm{~h}$, cooled. The obtained solid was crystallized from THF to give $\mathbf{1 3}$ in a good yield 70\%; $\mathrm{C}_{10} \mathrm{H}_{6} \mathrm{~N}_{4} \mathrm{~F}_{6} \mathrm{SO}_{2}\left(360 \mathrm{MW}\right.$ ), $\mathrm{S} \%$ : 7.99 (Calcd. 8.88); m.p. 195-2196 ${ }^{\circ} \mathrm{C}$; IRDRI-FT: $\left(\mathrm{cm}^{-1}\right) 3365,1597,1335,1280,1245,780,680 ; \mathrm{H}^{1} \mathrm{NMR}: \delta 8.1(\mathrm{~s}, 2 \mathrm{H}), 7.1-6.8(\mathrm{~m}, 4 \mathrm{H})$; UV Vis (EtOH): $\lambda_{\max } 276 \mathrm{~nm} .{ }^{13} \mathrm{C}$ NMR: $\delta 16.11\left(\mathrm{C}_{3}\right.$ of triazole), $116.7\left(\mathrm{C}\right.$ of $\left.\mathrm{CF}_{3}\right), 132.2(\mathrm{~N}-$ $\mathrm{C} 1$ of aryl), $129.9,127.3\left(\mathrm{C}_{2}\right.$ and $\mathrm{C}_{3}$ of aryl $)$, and $143.7 \mathrm{ppm}\left(\mathrm{O}_{2} \mathrm{~S}-\mathrm{C}_{4}\right.$ of aryl $)$.

\section{Results and Discussion}

It has been observed that introduction of fluorine atoms or $\mathrm{CF}_{3}$ group to heterocyclic systems acts as pharmacophore enhancing pharmacological properties of the compounds ${ }^{7}$. For example incorporation of fluorine atoms into indole ring tends to increase drug persistence by increasing its solubility in lipoid material and fat deposits in the body.

Thus, heterocyclization of acyl/benzoyl acetanilide 1a,b via refluxing with hydrazine hydrate $^{8,9}$ in THF led to the direct formation of 3-sulfanilamido-5-methyl/phenyl-1H-pyrazolines (2a,b). Fluorination of $\mathbf{2}$ by warming the mixture with hexafluoro acetic anhydride in THF produced 1-trifluoroacetyl-3-(trifluoroacetylaminoaryl-4-yl)-5-phenylpyrazoline $\mathbf{3}$ (Scheme 1).

A series of novel chiral imidazolines were prepared ${ }^{10}$ and used to develop the reactions of various aromatic aldehyde with un activated acrylates and or alkyl vinyl ketones were enantiomeric excesses obtained as metal-catalyzed reactions. Thus, 4-fluorobenzylidineoxazolin-5-one (4) used for the synthesis of polyfunctional imidazolone derivative $\mathbf{5}$ via a simple nucleophilic attack by sulfapyridine in boiling dry pyridine. Cyclo addition of compound 5 via refluxing with thiourea in ethanolic $\mathrm{NaOH}$ produced 6,7-dihydro-7( $p$-fluorophenyl)-2-phenyl-3-aryl-imidazolo[5,4-d]pyrimidine-5-one(6) (Scheme 2).

The use of heterocycles as chemical fertilizers to increase the yield of crops and as pesticides to eliminate all kinds of parasites able to attack the cultivations is more becoming important among these heterocycles thiazolidin-4-ones ${ }^{11-13}$. Thus, cycloaddition reactions of thioglycollic acid with a type of Schiff's bases 7 in boiling dry dioxan afforded 2,3-diarylthiazolidin-4-ones $(\mathbf{8 a}, \mathbf{8 b})$. Full fluorinated compound 9 was obtained from boiling $\mathbf{8 a}$ with hexafluoroacetic anhydride in dry THF (Scheme 3).

Sulfonamide azomethine derivatives containing $\mathrm{H}-\mathrm{C} \equiv \mathrm{N}$ group have wide medical applications ${ }^{14}$. Recently, sulfanilamidohydrazone bearing azomethine moiety showed important biological properties ${ }^{15}$. Thus, condensation of sulfa drugs such as sulfanilamide, sulfa benzamide and sulfa merazine with squaric acid (2:1 by moles) in boiling acetic acid furnished the bis-imino derivatives 10a-c, which upon boling with hexafluoroacetic anhydride in THF yielded 1,2(trifluoro -acetoxy)-3,4-di(p-sulfonamoyl phenyl)iminocyclo but-2-ene (11) (Scheme 4). 
<smiles>[R]C(=O)CC(=O)OCC</smiles>
b: ph

$\mathbf{1}(\mathbf{a}, \mathbf{b})$<smiles>[R]C(=O)CC(=O)Nc1ccc(S(N)(=O)=O)cc1</smiles>
$2(a, b)$<smiles>O=C(OC(=O)C(F)(F)F)C(F)(F)F</smiles><smiles>NS(=O)(=O)c1ccc(N(C(=O)OC(F)(F)F)c2cc(-c3ccccc3)n(C(=O)C(F)(F)F)c2)cc1</smiles>

Scheme 1

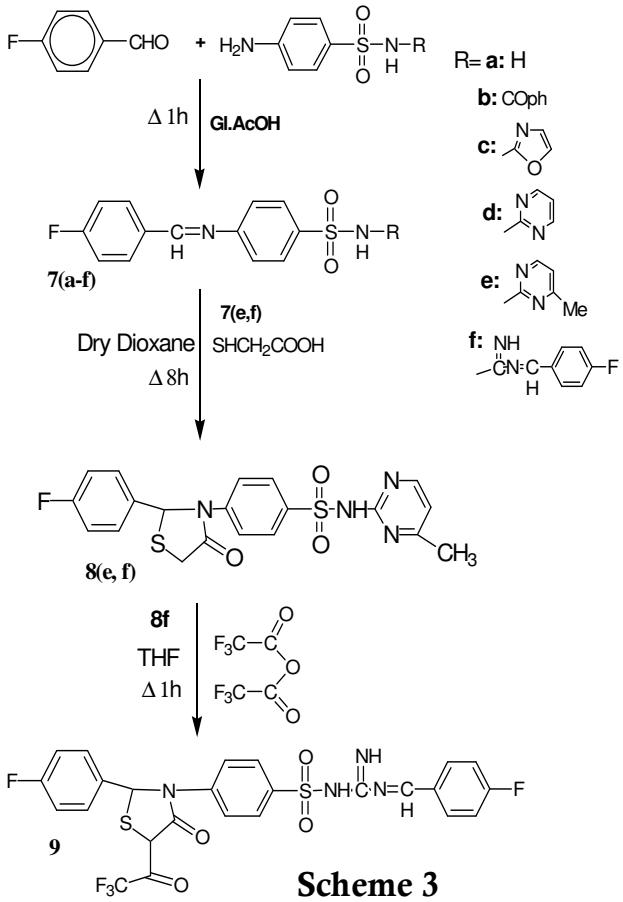

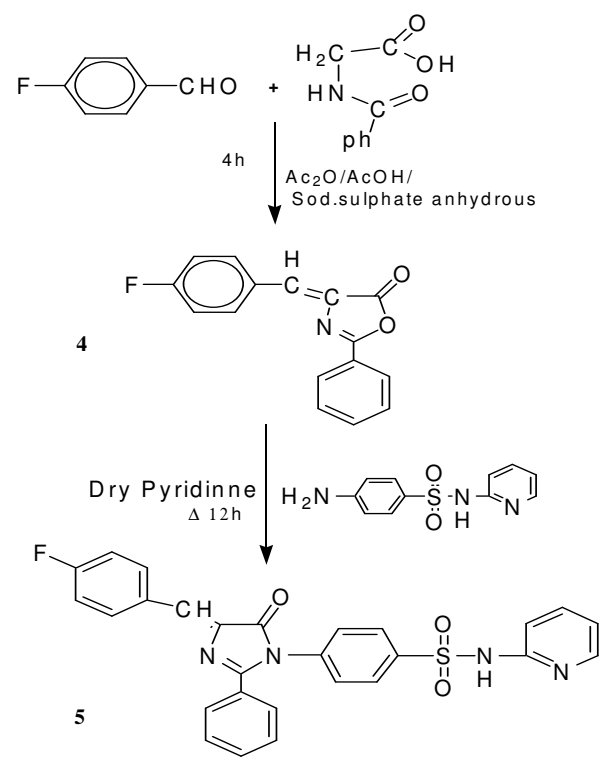

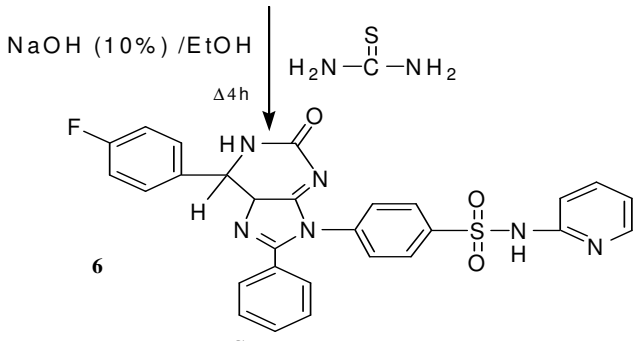

Scheme 2 


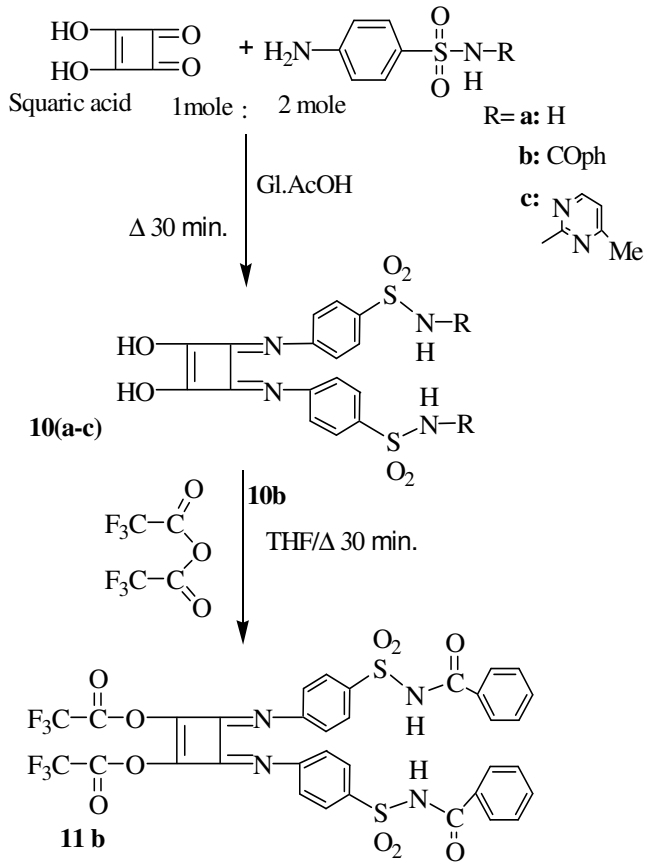

Scheme 4

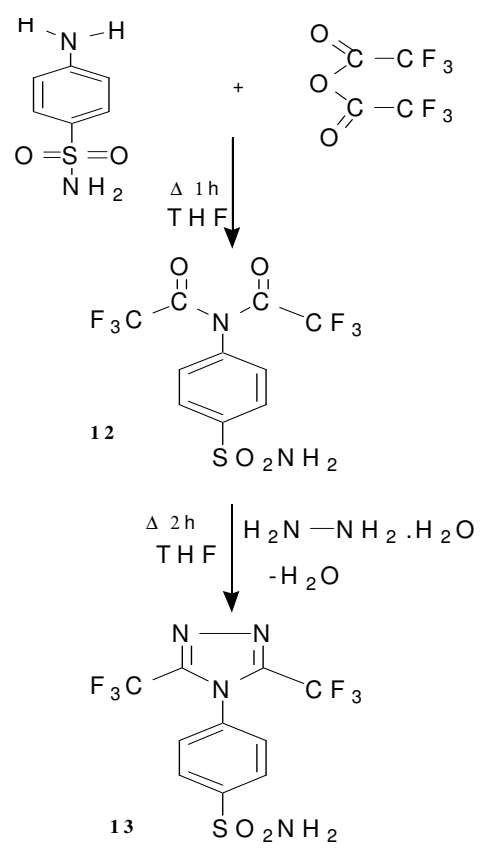

Scheme 5

Bi-nucleophilic attack on the 1,3-bicarbonyl compounds under mild conditions is an important process in synthetic organic chemistry, especially primary bi-nitrogen agents led to the formation of functionalized 1,2,4-triazoles as good ligand and antifungal agents ${ }^{16,17}$. Thus, 3,5-di(trifluoromethyl)-4-aryl-1,2,4-triazole $\mathbf{1 3}$ was isolated from treatment of sulfanilamide with excess hexafluoroacetic anhydride-THF to give $N$-di(trifluoroacetyl)sulfanilamide 12 followed by refluxing with hydrazine hydrate in boiling THF (Scheme 5).

\section{Photochemical probe activity}

Photodynamic therapy (PDT) is a cancer treatment leading to the selective destruction of malignancies by visible light in the presence of a photosensetizer and oxygen ${ }^{3,4}$. Upon the irradiation of visible light with appropriate wave length, the photosensetizer can drive molecular oxygen into excited triplet state transferring energy into ground state molecular oxygen to produce singlet molecular oxygen ${ }^{18}$. Activated singlet oxygen or reactive oxygen species (ROS) in general, plays an important role in cytotoxic effects on tumor tissues. PDT can be applied as an effective cancer treatment due to enhanced permeability and retention (EPR) effect in tumors in comparison with normal tissues and is easily controlled by limiting the area of light irradiation ${ }^{19}$. Thus, in present work we hope to synthesis of heterocyclic systems bearing both fluorine and sulfa moieties for treatment of Vitiligo instade of 8MPPUVA drug ${ }^{20}$.

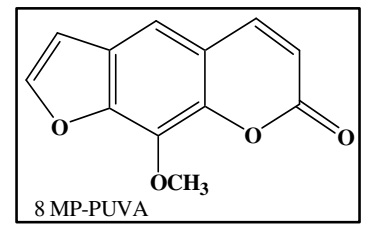




\section{Biocidal effects}

The synthesized compounds were tested in vitro against gram negative bacteria E. coli; $P$. aeuroginosa and K. pneumonia and gram positive bacteria $B$. subtillics, $S$. auereus and fungi A. fumigates; $C$. albicans using the agar diffusion disc method ${ }^{21}$ by placing pre-sterilized filter paper disks (6 $\mathrm{mm}$ in diameter) impregnated with $50 \mu \mathrm{g} /$ disk. DMF, which showed no inhibition zones, was used as a solvent. Inhibition zones (IZ) of the tested compounds (mm) were measured after $24-28 \mathrm{~h}$ incubation period $37^{\circ} \mathrm{C}$ for bacteria and after 5 days incubation period at $28^{\circ} \mathrm{C}$ for fungi (Table 1). The minimal inhibitory concentration (MIC) (Tables $2 \& 3$ ) method of the biologically active compounds was applied using different concentrations per disk against bacteria and fungi using nalidixic acid and nystatin as reference drugs.

Table 1. The preliminary screening of antimicrobial activity of the synthesized compounds

\begin{tabular}{|c|c|c|c|c|c|c|c|}
\hline \multirow{3}{*}{$\begin{array}{c}\text { Compd. } \\
\text { No. }\end{array}$} & \multicolumn{7}{|c|}{ Microorganisms / Inhibition Zone mmc } \\
\hline & \multicolumn{2}{|c|}{ Gram +ve Bacteria } & \multicolumn{3}{|c|}{ Gram +ve Bacteria } & \multicolumn{2}{|c|}{ Fungi } \\
\hline & B.S. & S.A. & E.C. & P.A. & K.P. & C.A. & A.F \\
\hline 5 & 1 & 12 & 10 & 15 & 16 & 8 & 8 \\
\hline $7 \mathbf{a}$ & 13 & 15 & 12 & 14 & 16 & 10 & 6 \\
\hline $7 b$ & 14 & 15 & 14 & 16 & 16 & 11 & 8 \\
\hline $7 e$ & 16 & 16 & 14 & 16 & 16 & 8 & 6 \\
\hline $7 f$ & 14 & 16 & 14 & 18 & 16 & 10 & 8 \\
\hline $8 \mathbf{e}$ & 11 & 11 & 10 & 12 & 16 & 12 & 6 \\
\hline $10 a$ & 12 & 16 & 10 & 12 & 16 & 8 & 6 \\
\hline 10b & 13 & 14 & 12 & 14 & 16 & 8 & 6 \\
\hline $10 \mathrm{c}$ & 16 & 16 & 14 & 16 & 16 & 9 & 6 \\
\hline 11b & 11 & 16 & 10 & 18 & 16 & 8 & 6 \\
\hline 13 & 16 & 20 & 14 & 16 & 16 & 8 & 6 \\
\hline$N a$ * & 32 & 30 & 30 & 12 & 22 & 6 & 6 \\
\hline$N y$. & 6 & 6 & 6 & 6 & 10 & 10 & 32 \\
\hline
\end{tabular}

*Na: Nalidixic acid, $30 \mu \mathrm{g} /$ disk, Bioanalize, Egypt. ${ }^{*} N y:$ Nystatin, manufactured by Pasteur Lab., Egypt, NS 100 units.Microorganisms: Gram +ve. : B.S.: Bacillus subtilis S.A.: Staphylacoccus aureus Gram -ve. : E.C. :Escherichia coli, P.A. : Pseudomonas aeuruginosa K.P. : Klebsiella Pneumonia Fungi : C.A. : Candida albicans (Aucc-1720) A.F. :Aspergillus fumigates (AuMc-1924). (The sensitivity of microorganisms of the compounds is defined in the following manners: Highly active: inhibition zone $\geq 12 \mathrm{~mm}$, Moderately active: inhibition zone 9-12 mm, Slightly active: inhibition zone 6-9 $\mathrm{mm}$, Not sensitive: inhibition zone $6 \mathrm{~mm}$.)

Table 2. MIC of the biological active compounds towards the Gram -positive bacteria*:

\begin{tabular}{|c|c|c|c|c|c|c|c|c|c|c|}
\hline \multirow{3}{*}{$\begin{array}{c}\text { Compd. } \\
\text { No. }\end{array}$} & \multicolumn{10}{|c|}{ Inhibition zones, $\mathrm{mm}$} \\
\hline & \multicolumn{5}{|c|}{ B. subtilis } & \multicolumn{5}{|c|}{ S. aureus } \\
\hline & 50 & 40 & 30 & 20 & 10 & 50 & 40 & 30 & 20 & 10 \\
\hline 5 & 12 & 10 & 6 & 6 & 6 & 12 & 10 & 6 & 6 & 6 \\
\hline $7 \mathbf{a}$ & 13 & 10 & 8 & 6 & 6 & 15 & 12 & 10 & 8 & 6 \\
\hline $7 b$ & 14 & 12 & 9 & 6 & 6 & 15 & 13 & 10 & 8 & 6 \\
\hline $7 e$ & 16 & 16 & 10 & 6 & 6 & 16 & 14 & 12 & 8 & 6 \\
\hline $7 f$ & 14 & 8 & 6 & 6 & 6 & 16 & 14 & 12 & 8 & 6 \\
\hline $8 \mathbf{e}$ & 11 & 9 & 6 & 6 & 6 & 11 & 11 & 6 & 6 & 6 \\
\hline 10a & 12 & 1 & 10 & 6 & 6 & 16 & 13 & 8 & 6 & 6 \\
\hline 10b & 13 & 10 & 8 & 6 & 6 & 14 & 10 & 9 & 6 & 6 \\
\hline 10c & 16 & 16 & 12 & 8 & 6 & 16 & 12 & 9 & 6 & 6 \\
\hline 11b & 11 & 11 & 6 & 6 & 6 & 16 & 11 & 9 & 6 & 6 \\
\hline 13 & 16 & 16 & 12 & 9 & 6 & 20 & 15 & 8 & 6 & 6 \\
\hline
\end{tabular}


Table 3. MIC of the biological active compounds towards Gram -negative bacteria

\begin{tabular}{|c|c|c|c|c|c|c|c|c|c|c|c|c|c|c|c|}
\hline \multirow{3}{*}{$\begin{array}{c}\text { Compd. } \\
\text { No. }\end{array}$} & \multicolumn{15}{|c|}{ Inhibition zones, $\mathrm{mm}$} \\
\hline & \multicolumn{5}{|c|}{ E. coli } & \multicolumn{5}{|c|}{ P. aeuruginosa } & \multicolumn{5}{|c|}{ K.Pneumonia } \\
\hline & 50 & 40 & 30 & 20 & 10 & 50 & 40 & 30 & 20 & 10 & 50 & 40 & 30 & 20 & 10 \\
\hline 5 & 10 & 8 & 8 & 8 & 6 & 15 & 11 & 10 & 8 & 6 & 16 & 12 & 10 & 8 & 6 \\
\hline $7 \mathbf{a}$ & 12 & 8 & 8 & 8 & 6 & 14 & 10 & 10 & 8 & 6 & 16 & 16 & 12 & 8 & 6 \\
\hline $7 b$ & 14 & 12 & 10 & 8 & 6 & 16 & 13 & 11 & 8 & 6 & 16 & 16 & 11 & 8 & 6 \\
\hline $7 e$ & 14 & 11 & 9 & 8 & 6 & 16 & 11 & 11 & 8 & 6 & 16 & 12 & 9 & 8 & 6 \\
\hline $7 f$ & 14 & 13 & 12 & 8 & 6 & 18 & 11 & 9 & 8 & 6 & 16 & 14 & 12 & 8 & 6 \\
\hline $8 \mathbf{a}$ & 10 & 8 & 8 & 8 & 6 & 12 & 9 & 8 & 8 & 6 & 16 & 11 & 9 & 8 & 6 \\
\hline 10a & 10 & 8 & 8 & 8 & 6 & 12 & 9 & 8 & 8 & 6 & 16 & 13 & 11 & 8 & 6 \\
\hline $10 \mathrm{~b}$ & 12 & 8 & 8 & 8 & 6 & 14 & 10 & 8 & 8 & 6 & 16 & 12 & 10 & 8 & 6 \\
\hline $10 \mathrm{c}$ & 14 & 8 & 8 & 8 & 6 & 16 & 14 & 8 & 8 & 6 & 16 & 11 & 9 & 8 & 6 \\
\hline $11 b$ & 10 & 8 & 8 & 8 & 6 & 18 & 14 & 12 & 8 & 6 & 16 & 11 & 10 & 8 & 6 \\
\hline 13 & 14 & 12 & 10 & 8 & 6 & 16 & 12 & 10 & 8 & 6 & 16 & 11 & 10 & 8 & 6 \\
\hline
\end{tabular}

Antimicrobial assays using UV (366 $\mathrm{nm})$ light

This test was performed as mentioned before but the Petri-disks containing microorganisms and the testing compounds were subjected to UV light $(366 \mathrm{~nm})$ for $3 \mathrm{~h}$ before transferred to the incubation periods (Table 4).

Table 4. Preliminary screening using UV (366 nm) light

\begin{tabular}{|c|c|c|c|c|c|c|c|}
\hline \multirow{3}{*}{$\begin{array}{c}\text { Compd. } \\
\text { No. }\end{array}$} & \multicolumn{7}{|c|}{ Microorganisms (Inhibition zones in mm) } \\
\hline & \multicolumn{2}{|c|}{ Gram +ve bacteria } & \multicolumn{3}{|c|}{ Gram -ve bacteria } & \multicolumn{2}{|c|}{ Fungi } \\
\hline & B.S. & S.A. & E.C. & P.A. & K.P. & C.A. & A.F. \\
\hline 5 & 13 & 12 & 10 & 17 & & 9 & \\
\hline $7 \mathbf{a}$ & 13 & & & 16 & & 13 & \\
\hline $7 \mathbf{b}$ & 15 & No & No & 16 & $\begin{array}{l}\text { No } \\
\text { change }\end{array}$ & 14 & No \\
\hline $7 e$ & 17 & change & change & 18 & & 8 & change \\
\hline $7 f$ & 16 & & & 20 & & 13 & \\
\hline $8 e$ & 13 & & & 14 & & 16 & \\
\hline 10a & 13 & & & 15 & & 10 & \\
\hline 10b & 13 & No & & 18 & & 10 & \\
\hline 10c & 18 & change & $\begin{array}{l}\text { cho } \\
\text { change }\end{array}$ & 22 & $\begin{array}{l}\text { cho } \\
\text { change }\end{array}$ & 10 & $\begin{array}{l}\text { cho } \\
\text { change }\end{array}$ \\
\hline 11b & 18 & & & 20 & & 10 & \\
\hline 13 & 20 & & & 20 & & 12 & \\
\hline - & * & - & - & $*$ & - & $*$ & - \\
\hline
\end{tabular}

*Increasing in activity by using UV light (366 $\mathrm{nm}$.) 


\section{Conclusion}

The present work reports a new investigation of fluorine bearing heterocyclic nitrogen systems derived from sulfa drugs analogs as potential inhibitor for Vitiligo disease. All the derivatives showed highly to moderate activities against tested microorganisms in compare with standard antibiotic for Vitiligo as nystatin and nalidixic acid.

The obtained data suggest that fluorine Schiff's base 7, imino squaric acid $\mathbf{1 0}$ and hexa fluoro-1,2,4-triazole (13) should be considered a good scaffold for inhibitors of the microorganisms which cause a Vitiligo disease.

From obtained results of the Biocidal effects of the tested compounds (Tables 1-4) we conclude that:

- In general, all the tested compounds were more highly active towards all tested microorganisms, in compare with nystatin antibiotic.

- MIC of all the active tested compounds showed activities more than nystatin, especially toward B. subtilis, S.aureus and E.coli, P.aeuroginosa and K. pneumonia

- After using UV Visible light, the tested compounds showed an additional activity especially towards B. subtilis, P.aeuroginosa and C.albicans.

- The fluorinated heterocyclic nitrogen systems 7, 10 \& 13 exhibited a highly biocidal effects, which is mainly due to connection of fluorine groups at the terminal of nitrogen/oxygen systems causing a type of biodynamic electron-motion which led to use these systems as photochemical probe agents.

\section{Acknowledgment}

We greatly acknowledge Prof. Dr. Z.El-Bazza and her co-workers, Phrmamicrobiological Lab., National Centre for Radiation Research and Technology, Cairo, Egypt, for financial support to carrying out the antimicrobial assays, especially photo-synthetization activity of cancer. I also indebted to the King Fahd Center at KAU for all laboratory facilities.

\section{References}

1. Al-Bayati F A and Suliman K D, Turk J Biol., 2008, 32, 57-62.

2. (a) Abdel-Rahman R M, Pharmazie, 1999, 54(11), 791-804; (b) Abdel-Rahman R M, IlFarmaco, 1991, 46(2), 379-389; (c) Abdel-Rahman R M, IlFarmaco, 1992, 47(3), 319.

3. Ko Y J, Yun K J, Kang M S, Park J, Lee K T, Park S B and Shin J H, Bioorg Med Chem Lett., 2007, 17, 2789-2794.

4. Brown S B, Brown E A and Walker I, Lancet Oncology, 2004, 5(8), 497-508.

5. Konev A S, Novikov M S, Khlebnikov A F and Tehrani K A, J Fluorine Chem., 2007, 128, 114-119.

6. Dolzhenko A V, Tan B J, Chiu G and Chiu W, J Fluorine Chem., 2008, 129(5), 429-434

7. Smart B E, J Fluorine Chem., 2001, 109, 3-11.

8. Abdel-Rahman R M, Seada M and Fawzy M M, Pak J Sci Ind Res., 1991, 34(12), 465-469.

9. Jain R, Padmaja P, Bhadauria J and Tomar S, J Indian Chem Soc., 2000,77, 42.

10. Xu J, Guan Y, Yang S, Ng Y, Peh G and Hong Tan C H, Chem Asian J., 2006, 1, 724-729.

11. Adel-Rahman R M, Boll Chim Farm., 2001, 140, 401-410.

12. Patel K D, Mistry B D and Desai K R, J Indian Chem Soc., 2006, 83, 94-96.

13. Srivastava S. K, Jain A and Srivastava S. D, J Indian Chem Soc., 2006, 83, 1118-1123. 
14. Messeder J C, Tinoco L W, Souza E M, Sants Rita R, deCastro S L and FiguerroaVillar J D, Bioorg Med Chem Lett., 1995, 5, 3079.

15. Jain R, Bhadauria A and Tomar S, J Indian Chem Soc., 2007, 84,197.

16. Liu S, Qian X, Song G, Chen J and Chen W, J Fluorine Chem., 2000, 105, 111-115.

17. Abdel-Rahman R M, Seada M and Abdel-Magid M, Indian J Heterocycl Chem., 1993, 3, 9.

18. De Rosa, Crutchley M C and Coord R J, Chem Rev., 2002, 233, 351-371.

19. Allison R R, Downine G H, Cuenca R, Hu X H, Chileds C J and Sibata C H, Photodiagnosis Photodynamic Ther., 2004, 1(1), 27-42.

20. Konev A S, Novikov M S, Khlebnikov A F and Tehrani K A, J Fluorine Chem., 2007, 128, 114-119.

21. Weinstein $\mathbf{M} \mathbf{J}$ and Nagman $\mathrm{G} \mathbf{H}$, In Antibiotics, Elsevier Scientific Publishing company, 1978, Amesterdam. 


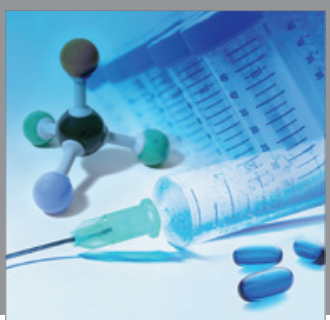

International Journal of

Medicinal Chemistry

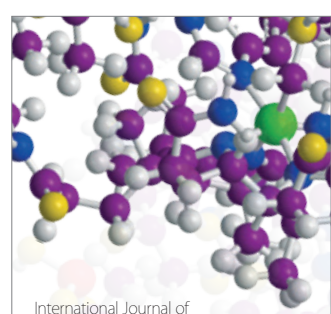

Carbohydrate Chemistry

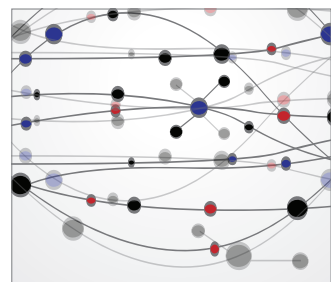

The Scientific World Journal
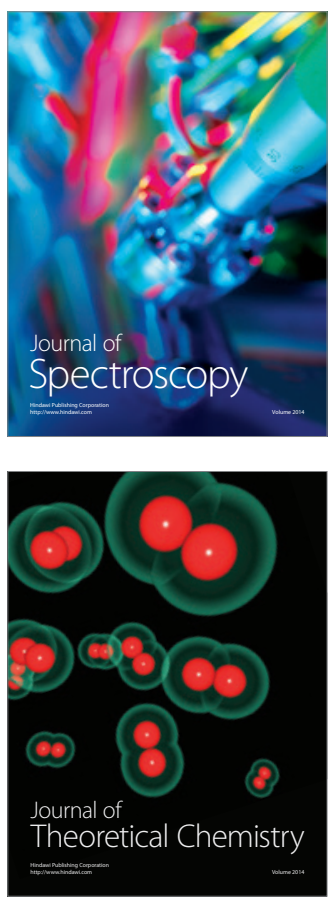
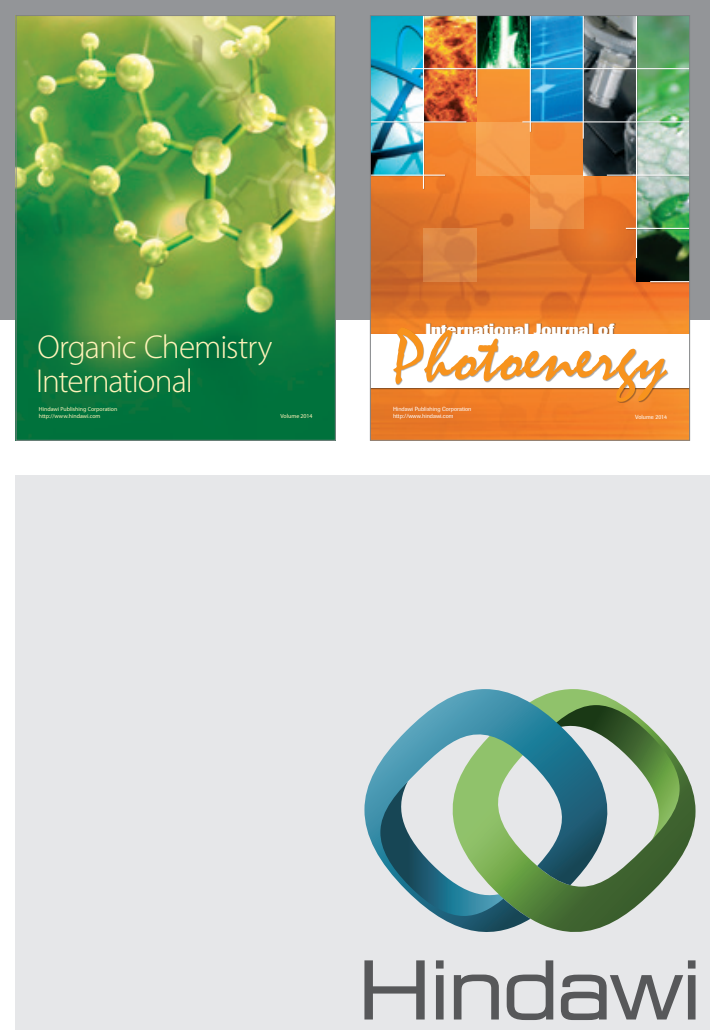

Submit your manuscripts at

http://www.hindawi.com
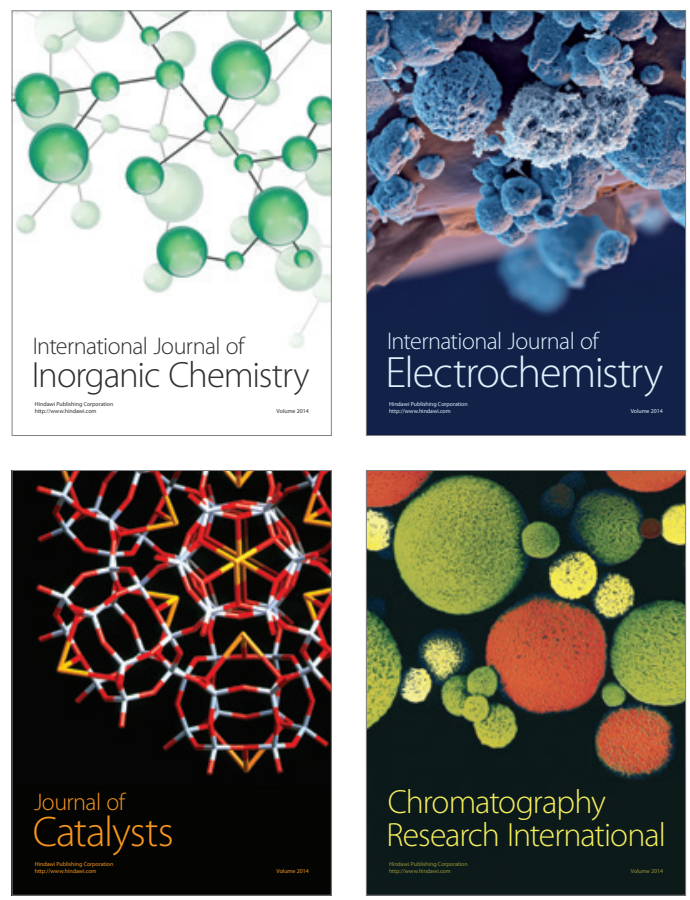
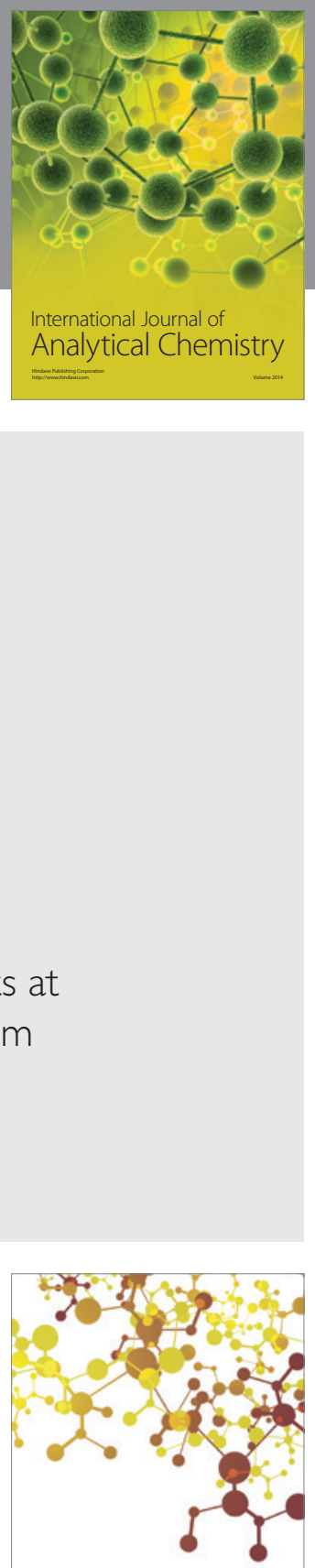

Journal of

Applied Chemistry
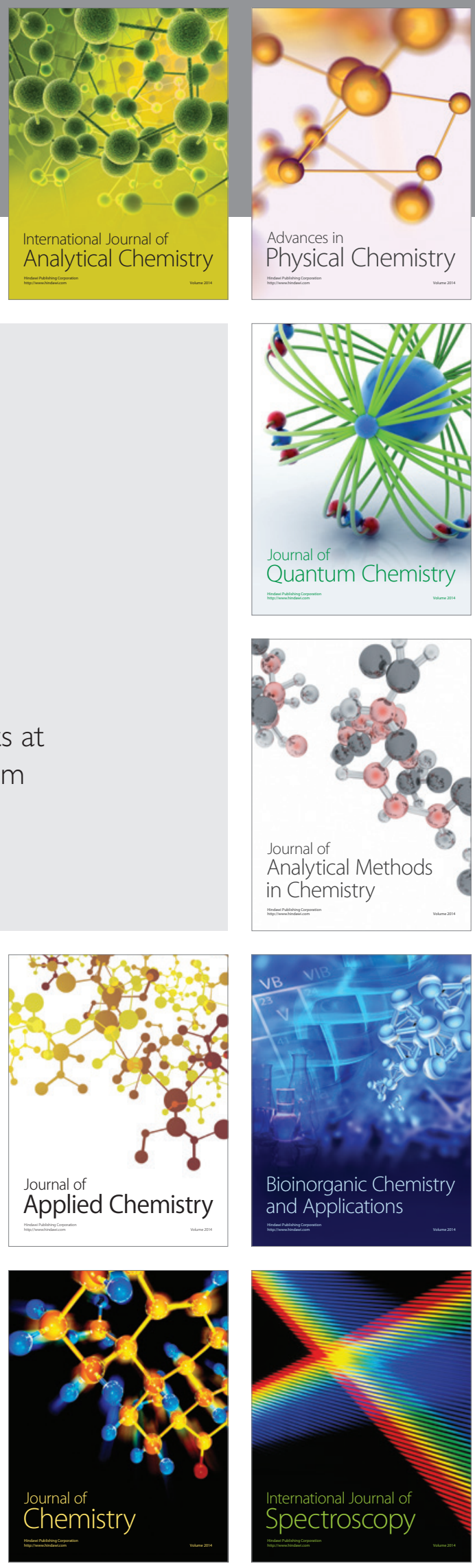